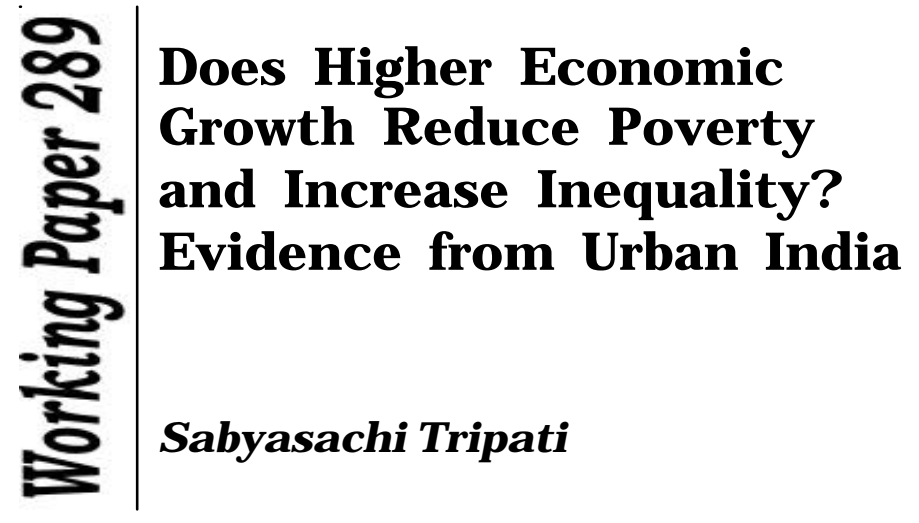




\section{ISBN 978-81-7791-145-9}

\section{(C) 2012, Copyright Reserved}

The Institute for Social and Economic Change,

Bangalore

Institute for Social and Economic Change (ISEC) is engaged in interdisciplinary research in analytical and applied areas of the social sciences, encompassing diverse aspects of development. ISEC works with central, state and local governments as well as international agencies by undertaking systematic studies of resource potential, identifying factors influencing growth and examining measures for reducing poverty. The thrust areas of research include state and local economic policies, issues relating to sociological and demographic transition, environmental issues and fiscal, administrative and political decentralization and governance. It pursues fruitful contacts with other institutions and scholars devoted to social science research through collaborative research programmes, seminars, etc.

The Working Paper Series provides an opportunity for ISEC faculty, visiting fellows and PhD scholars to discuss their ideas and research work before publication and to get feedback from their peer group. Papers selected for publication in the series present empirical analyses and generally deal with wider issues of public policy at a sectoral, regional or national level. These working papers undergo review but typically do not present final research results, and constitute works in progress. 


\title{
DOES HIGHER ECONOMIC GROWTH REDUCE POVERTY AND INCREASE INEQUALITY? EVI DENCE FROM URBAN INDIA
}

\author{
Sabyasachi Tripathi*
}

\begin{abstract}
This paper calculates select urban inequality and poverty indices and finds out their policy linkages. In addition, the determinants of urban poverty and inequality are estimated by using data of 52 large cities in India. The main results show that higher city economic growth and large city population agglomeration are associated with reduction in city poverty and increase in inequality between cities.
\end{abstract}

\section{JEL Classification: R11, D 63}

Key Words: Urban Economic Growth, Inequality, Poverty, Urban India.

\section{Introduction}

Urban India has been experiencing increasing economic growth, geographical expansion and demographic growth. For instance, the share of urban economy in the total net domestic product (NDP) increased from 37.65 per cent in 1970-71 to 52.02 per cent in 2004-05 and accounted for about 6.2 per cent growth rate of urban NDP from 1970-71 to 2004-05 at constant prices (1999-00). Similarly, the urban geographical area has increased by about 103 per cent, i.e., from 38,509.28 square kilometres (1.32 per cent of total area) in 1971 to $78,199.66$ square kilometres (2.38 per cent of total area) in 2001. Urban population as a percentage of total population increased from 19.9 per cent in 1971 to 27.8 per cent in 2001.

At the same time, there exists a wide ruraturban disparity in per capita consumption in India. For instance, Vaidyanathan (2001) finds that the per capita total consumption (or food consumption) in urban areas is 63 (or 41) per cent higher than in rural areas. Most importantly, India-Urban Poverty Report 2009 by Government of India (2009) finds that about 80 million people were estimated as poor (measured by poverty head count ratio) in the cities and towns of India in 2007-08, and urban poverty in some of the larger states is higher than that of rural poverty, a phenomenon generally known as 'Urbanization of Poverty'.

\footnotetext{
* PhD scholar in Economics at Centre for Economics Studes and Policy, Institute for Social and Economic Change, Bangalore-560072, India; email: sabya.tripathi@gmail.com

This paper is a part of my Doctoral Dissertation. I would like to thank my PhD supervisor Pof M R Narayana. But for his constant guidance and inspiration it would not have been possible for me to write this paper. I thank Prof Meenakshi Rajeev, Ms B P Vani, Dr Veerashekharappa, Dr C Nanjundaiah, Dr Elumalai Kannan and Ms Amrita Ghatak for their helpful comments and discussions. Finally, I would like to thank Dr Abdelkrim Araar for his comments and suggestions in elucidating the link between inequality and poverty, as also his permission to use the Distributive Analysis Stata Package (DASP) for the empirical estimation. However, the usual disclaimer applies.
} 
Urban India is also characterized by intra-urban inequalities; as per the 61st Round of National Sample Survey (NSS) of 2004-05 on consumer expenditure, the urban consumption inequality measured by Gini coefficient is about 0.38 . A reduction in consumption inequality and poverty between rural and urban India as well as within urban India is an important component of the inclusive growth strategy of the ongoing XI Five-Year Plan (2007-12); it is also the growth strategy enunciated in the Approach to the Twelfth Five-Year Plan (2012-17).

There is a vast body of literature that measures poverty and inequality by rural and urban sectors and at national and state levels, especially since 1990. In general, these studies highlight the increasing inequality between urban and rural sectors (Deaton and Kozel 2005; Sen and Himanshu 2004; Sundaram and Tendulkar 2003). Using per capita consumption expenditure as a measure of welfare, Deaton and Dreze (2002) find that inter-state inequality increased between 1993-1994 and 1999-2000 and that urban-rural inequality increased not only throughout India but also within states. Jha (2002) finds higher inequality in both urban and rural sectors during the postreform period compared to the early 1990 s.

In the context of city-level inequality, Kundu (2006) finds that there is gross inequality in the matter of economic base between the million-plus cities (one million or more population), medium towns (50,000 to one million population) and small towns (less than 50,000 population) in terms of employment, consumption and poverty. In particular, consumption expenditure differences across size classes of urban centres are indicative of severe intra- urban inequality. The study finds that as of 19992000 , the per capita monthly consumption expenditure of million-plus cities was Rs 1,070, about 53 per cent higher than that of small towns. In contrast, India: Urban Poverty Report 2009 by the Government of India (2009) finds that across the Indian states, poverty is negatively correlated with the level of urbanization, and large and medium cities have lower incidence of poverty than small cities in India. A World Bank study (World Bank 2010) finds that poverty is more widespread in very small towns than in large cities. Most importantly, Gangopadhyay et al (2010) study applies the small area estimation methodology in three states of India in 2004-05 and confirms that in West Bengal, Orissa and Andhra Pradesh the poverty level in large cities is much lower than small towns.

The above review of select studies shows that urban India is characterzed by higher poverty and inequality. In this context, this paper focuses on the two key objectives: First, to measure the extent of urban inequality and poverty across cities and demonstrate the link between them by emphasizing on the share of inequality components (i.e., between- and within-group inequalities) in total poverty, in six geographical urban zones of India. Secondly, to identify and estimate the economic determinants of city inequality and poverty, using unit (or individual) level data of NSS $61^{\text {st }}$ Round of consumer expenditure survey and city-level data for other important variables. It is assumed that this is a pioneering effort for measuring inequality and poverty at large city levels and establishing an empirical link between inequality and poverty, with a view to suggesting policy prescription for reducing poverty and inequality in urban India. Moreover, the paper also sheds light on the impact of urban agglomeration and urban economic growth on urban inequality and poverty.

The rest of the paper is organized as follows: Section 2 measures the selected poverty and inequality indices at city level. Inter-urban variation in inequality and poverty is discussed Section 3. 
Section 4 presents the relevant determinants of urban inequality and poverty by using OLS regression estimation. Finally, major conclusions and implications are given in Section 5.

\section{Measurement of Select Poverty and I nequality I ndices at District Level}

Inequality is measured by the familiar Gini coefficient. To check the onfidence interval of the Gini coefficient values, Jackknife standard errors are calculated. ${ }^{1}$ Poverty is measured by Poverty Headcount Ratio (PHR), Poverty Gap Ratio (PGR) and Squared Poverty Gap Ratio (SPGR). The importance of using these three poverty indices is discussed well in Hand-Book of Poverty and Inequality (specifically in Chapter 4) by Haughton and Khandker (2009).

\subsection{Data Used}

Due to the non-availability of income data at the individual level, urban monthly per capita consumer expenditure (MPCE) data from the $61^{\text {st }}$ Round of National Sample Survey (NSS) 2004-05 is used for the estimation of city-level income inequality and poverty by considering total number of sample urban persons of the respective city district. ${ }^{2}$ The $61^{\text {st }}$ Round on consumption expenditure survey follows both Uniform Recall Period (URP) and Mixed Recall Period (MRP). ${ }^{3}$ To measure urban poverty, the new poverty lines as worked out by the Expert Group, which was set up by the Planning Commission of India in 2009 under the Chairmanship of Prof Suresh Tendulkar to suggest a new poverty line, is considered. ${ }^{4}$

However, as India's official estimates do not provide city-level poverty line, state-specific urban poverty lines are used for measuring city-level poverty for the cities located in the corresponding states ${ }^{5}$ Following the Expert Group's suggestion, MRP-based poverty estimation is considered, as MRP-based estimates capture the household consumption expenditure of the poor households on low-frequency items of purchase more satisfactorily than URP. ${ }^{6}$ On the other hand, to measure urban inequality, commonly used URP-based estimation is considered, as data collected for 30-day recall period are more authentic due to higher response from the respondents. ${ }^{7}$

\subsection{Status of Poverty and I nequality at District Level}

Gini Coefficients for 52 large city districts (see Appendix Table 1 for details) are presented in Appendix Table 2. Lower values in the Gini coefficient are observed for the districts of Amritsar, Kamrup, Aligarh, Meerut and Jalandhar than other districts considered. In contrast, districts which have registered a higher value of Gini coefficient are Ludhiana, Agra, Durg, Jaipur and Visakhapatnam. In addition, the standard errors for these estimates are small; thus inequality in urban area- as measured by the Gini coefficient - is statistically the highest for Ludhiana and the lowest for Amritsar. The calculated values of PHR (see Table 2 in Appendix) show that the five city districts of Aurangabad, Nasik, Khordha, Solapur and Allahabad are at the top in descending order in terms of higher urban poverty levels. On the other hand, the five city districts of Bangalore, Thiruvananthapuram, Mumbai, Kota and Chennai are at the lower bottom in the ascending order in regard to lower level of poverty. The calculated values of 
PGR show that among the 52 city districts under study, abject poverty is high in Aurangabad, Nasik, Solapur,

Khordha and Barddhaman. In contrast, Bangalore, Thiruvananthapuram, Mumbai, Chennai, and Kolkata have lower levels of poverty. The calculated values of SPGR show that poverty level is lower in Bangalore, Mumbai, Chennai, Jodhpur, and Thiruvananthapuram. In contrast, Aurangabad, Nashik, Khordha, Solapur and Kozhikode show higher levels of poverty. The poverty level of Bangalore is the lowest among 52 large city districts as per PHR, PGR, and SPGR. On the other hand, Aurangabad and Nashik have the highest and second highest level of poverty respectively among 52 large city districts as per PHR, PGR, and SPGR. However, other 49 city districts (except Bangalore, Aurangabad and Nashik) are at different ranks (or different levels of poverty) according to the value of PHR, PGR and SPGR. The Spearman's rank correlation coefficients (or Spearman's rho) have been calculated to examine the changing relative ranks of cities by PHR, PGR and SPGR. Table 1 presents the calculated values of the Spearman's rho. The results do not indicate any remarkable change (as correlation coefficient is very high) in relative ranking by PHR, PGR and SPGR. Therefore, if a city shows higher urban poverty level by calculated values of PHR, the calculated values of PGR and SPGR will also be the identical.

Table 1: Spearman's Rank Correlation Coefficients between the Poverty I ndices

\begin{tabular}{|l|c|c|c|}
\hline & PHR & PGR & SPGR \\
\hline PHR & 1 & & \\
\hline PGR & $0.95^{*}$ & 1 & \\
\hline SPGR & $0.90^{*}$ & $0.98^{*}$ & 1 \\
\hline
\end{tabular}

$*$ indicates statistical significance at $1 \%$ level.

It is also observed that by and large, districts with lower mean MPCE will have higher poverty levels. For instance, Aurangabad, Khordha, Solapur, and Allahabad show higher level poverty with lower level of mean MPCE. Moreover, Table 2 presents the poverty and inequality situations for different size of cities at the aggregate level in three categories; marginalized group, others and total (marginalized plus others group). Across the three categories, the lowest levels of inequality are observed among the marginalized group. However, the highest level of poverty among all size groups is found in the marginalized group. On the other hand, the 'others category' has the lowest level of poverty and highest level of inequality among all size of cities. In particular, the lowest levels of poverty are observed for mega cities among three categories. 
Table 2: Measurement of Poverty and I nequality

\begin{tabular}{|l|l|c|c|c|c|c|}
\hline \multicolumn{2}{|c|}{} & $\begin{array}{c}\text { All } \\
\text { India } \\
\text { Urban }\end{array}$ & $\begin{array}{c}\text { Large } \\
\text { cities } \\
\mathbf{( 5 2} \\
\text { cities) }\end{array}$ & $\begin{array}{c}\text { Metropolit } \\
\text { an Cities } \\
\text { (30 cities) }\end{array}$ & $\begin{array}{c}\text { Mega } \\
\text { cities } \\
\text { (6 cities) }\end{array}$ & $\begin{array}{c}\text { Total all } \\
\text { India } \\
\text { urban } \\
\text { (except } \\
\mathbf{5 2} \text { cities) }\end{array}$ \\
\hline \multirow{4}{*}{ Gini Index } & Marginalized Group & 0.33 & 0.35 & 0.34 & 0.32 & 0.32 \\
\cline { 2 - 7 } & Others & 0.38 & 0.40 & 0.41 & 0.39 & 0.36 \\
\cline { 2 - 7 } & Total & 0.38 & 0.40 & 0.40 & 0.38 & 0.35 \\
\hline \multirow{2}{*}{$\begin{array}{l}\text { Headcount } \\
\text { Index (in }\end{array}$} & Marginalized Group & 34 & 25 & 24 & 8 & 39 \\
\cline { 2 - 7 } & Others & 16 & 11 & 10 & 6 & 19 \\
\cline { 2 - 7 } & Total & 26 & 18 & 17 & 7 & 30 \\
\hline \multirow{2}{*}{$\begin{array}{l}\text { Sample size } \\
\text { (Persons) }\end{array}$} & Marginalized Group & 121411 & 26871 & 18917 & 5167 & 94540 \\
\cline { 2 - 7 } & Others & 85118 & 23186 & 17425 & 8172 & 61932 \\
\cline { 2 - 7 } & Total & 206529 & 50057 & 36342 & 13339 & 156472 \\
\hline
\end{tabular}

Source:Author's calculation using NSS $61^{\text {st }}$ Round of National Sample Survey in 2004-05 on consumer expenditure.

Notes: 1. Marginalized Group includes Scheduled Tribes, Scheduled Castes, and Other Backward Classes.

2. Metropolitan cities (population more than one million) and Mega cities (cities with five million-plus population) as per 2001 census.

3. All India urban poverty line for 2004-05 which is worked out by Tendulkar Methodology is used to calculate head count poverty index.

Most importantly, among the six mega cities (population over five million) districts, the estimates of poverty is lowest in Bangalore and highest in Hyderabad. Stochastic dominance tests have been performed to explore the robustness of comparison between the poverty situations of each mega city districts with the rest of the urban area of the respective states. Appendix Figure 1 presents the result of the first order stochastic dominance, according to which Bangalore, Chennai, Kolkata, Hyderabad and Mumbai dominate the rest of the urban regions of Karnataka, Tamil Nadu, West Bengal, Andhra Pradesh and Maharashtra, respectively. This conclusion is drawn as the poverty incidence curve (cumulative distribution function) of these five mega city districts is consistently below than the other urban regions of the respective states over a wide range of interval. However, in the case of Delhi city represented by North-West Delhi District and the other region of Delhi, ascertaining the first-order poverty dominance is inconclusive as there are more than one interaction points. ${ }^{8}$ Given that first-order dominance could not be ascertained, higher-order dominance (i.e. second-order) is tested; it is found that there is no clear dominance of North-West Delhi District over the other regions of Delhi. Thus, mega cities show lower level of poverty situation than other cities (or urban regions) located in the corresponding states. 


\section{I nter Urban Variation in I nequality and Poverty}

In order to find the linkages between urban inequality and poverty, urban India is divided in to the following six regions: North region (Haryana, Uttaranchal, Himachal Pradesh, Jammu and Kashmir, Uttar Pradesh, Delhi and Punjab), North-East region (Assam, Tripura, Manipur, Meghalaya, Nagaland, Arunachal Pradesh, and Mizoram), West region (Gujarat, Maharashtra, Goa, and Rajasthan), South region (Andhra Pradesh, Karnataka, Kerala, Tamil Nadu, and Pondicherry), East region (West Bengal, Orissa, Bihar, J harkhand, and Sikkim), and Central region (Madhya Pradesh and Chhattisgarh).

Appendix Table 3 gives the result of decomposition of the FGT index (for alpha $=0$ ) by the six zones. Over 29 per cent of total poverty is attributed to the population group that lives in Northern zone, although this zone comprises about 27 per cent of the total population. On the other hand, with an identical szze of population share, only 22 per cent of total poverty is attributed to the population group that lives in the Western zone. Appendix Figure 2 shows that within poor group has a lower contribution to the total inequality (measured by the Gini index) than that of the non-poor group, while a major part of the inequality is explained by the inequality between the poor and the non poor groups.

In Appendix Table 4, the Gini index is decomposed by the six Indian geopolitical urban zones. It is seen that the within group inequality contributes (23 per cent) higher than the between group inequality (12 per cent) to total inequality. Most importantly, overlap group expenditure explains the residue component and this component can be attributed to between groups component (Araar 2006). The highest level of the overlap component indicates that the level of identification of groups, based on these six geopolitical zones, is low. It is important to note here that the group identification by a given indicator, like the household consumption expenditure, is high when populations groups are identified only by using this indicator. ${ }^{9}$

The distribution of consumption expenditure depends on average consumption expenditure, the between-group inequality and the within-group inequality. In Appendix Figures 3 and 4, the magnitude of the contribution of each component is shown according to the poverty line when the parameter alpha $=0$ and alpha $=1$. For a given level of poverty the contribution of each of the three components to the total poverty is estimated. However, when the poverty line varies, the contribution of each of the three components also varies. For instance, for alpha $=0$ and where the poverty line exceeds the average expenditure, the between-group inequality helps to reduce poverty, because the between-group inequality makes that some individuals have incomes higher than the poverty line and others have incomes lower than the poverty line. In case of urban India when the poverty line (Rs 578.8 in 2004-05) is below the average monthly per capita expenditure (Rs 1,052 based on URP), the contribution of this average is nil. For the headcount index, the contribution of inequality component is greater than zero when poverty line is below the average per capita consumption expenditure.

The decomposition of the FGT index by average monthly per capita expenditure and inequality components across zones is presented in Appendix Table 5 and 6 for alpha $=0$ and alpha $=1$, respectively. The results show that while the within-group inequality contributes more to the total inequality as measured by the Gini index, its contribution to total poverty is very high. 


\section{Determinants of Urban I nequality and Poverty}

\subsection{Framework for Estimation of Determinants of Urban Inequality}

Following Glaeser et al (2009), the estimable model for determinants of urban inequality is as follows:

$\mathbf{G i}=\alpha_{0}+\alpha_{1} \mathbf{X}_{1}+\alpha_{2} \mathbf{X}_{2}+\alpha_{3} \mathbf{X}_{3}+\alpha_{4} \mathbf{X}_{4}+\mathbf{u}_{1}$

$G_{i}$ is Gini coefficient value of a city, $X_{1}$ refers to city population agglomeration, $X_{2}$ stands for per capita city output or city output growth, and $X_{3}$ refers to level of human capital accumulation of a city, and $X_{4}$ refers to city poverty rate. Equation (1) is estimated by the technique of OLS. In equation (1), the expected sign of $\alpha_{2}$ is positive (or negative), depending on the different stages of development (or urbanization process) at national level. ${ }^{10}$

As Glaeser et al (2009) find an increasing positive relationship between areapopulation and the Gini coefficient across American metropolitan areas, the expected effect of city population agglomeration on city inequality is positive (i.e., $\alpha_{1}>0$ ). The effect of human capital accumulation on inequality depends on the level of education that is represented by $X_{3}$. For instance, Glaeser et al (2009) find that the share of college graduates (or the share of high school graduates) has a positive (or negative) effect on city inequality due to differences in the returns to skill. Due to paucity of city-level data, large city district-level primary gross enrollment ratio (PGER), upper primary gross enrollment ratio (UPGER) and literacy rate are considered as the basic measure of human capital accumulation of the city. Expected sign of $\alpha_{3}$ can be positive or negative. A positive impact of poverty on inequality (i.e., $\alpha_{4}>0$ ) is expected, as Le (2010) finds a similar relationship in case of Vietnam from 1996 to 2004 by using the provincial data and data from household living standard surveys.

Based on the current Indian scenario, it is clear that large city population agglomeration, per capita city output growth rate, human capital accumulation and higher poverty rate have a positive effect on city inequality.

\subsection{Framework for Estimation of Determinants of Urban Poverty}

Following Le (2010), the following specification is used to examine the determinants of urban poverty:

$$
\mathbf{P i}=\alpha_{00}+\alpha_{11} \mathbf{X}_{11}+\alpha_{22} \mathbf{X}_{22}+\alpha_{33} \mathbf{X}_{33}+\alpha_{44} \mathbf{X}_{44}+\mathbf{u}_{11}
$$

$P_{i}$ is poverty head count ratio of a city, $X_{11}$ refers to city population agglomeration, $X_{22}$ stands for per capita city output or city output growth, $X_{33}$ refers to level of human capital accumulation of a city and $\mathrm{X}_{44}$ refers to city inequality. Equation (2) is estimated by the technique of OLS.

In equation (2), a negative impact of large city agglomeration on city poverty rate (i.e., $\alpha_{11}<$ 0 ) is expected as large cities have higher productivity, wages and capital per worker (World Bank, 2004). As absolute poverty tend to fall with higher economic growth combined with low level of inequality, a negative sign of $\alpha_{22}$ is expected. Following Ali and Tahir (1999) and Le (2010), a positive effect of inequality on poverty rate (i.e., $\alpha_{44}>0$ ) is expected. Finally, a negative effect of human capital accumulation on city poverty rate is expected as higher share of school (or college) education is found 
to have created better work opportunity for the people and therefore could lead to reduction of poverty level (i.e., $\left.\alpha_{33}<0\right)$.

Urban India is experiencing an increasing trend of large city population agglomeration, per capita city output and its growth, human capital accumulation, inequality and a reduction of poverty rate. Therefore, a negative effect of large city population agglomeration, per capita city output and its growth, human capital accumulation on city poverty rate and a positive effect of higher inequality on city poverty rate are predicted.

\subsection{Measurement of Variables and Data Sources}

Table 3 summarizes the descriptions, measurements and data sources of all the variables used in the OLS estimation of Equations (1) and (2).

Table 3: Measurement and Data Sources of the Variables

\begin{tabular}{|c|c|c|}
\hline Variable & Measurement & Data Source(s) \\
\hline \multicolumn{3}{|c|}{ Dependent variables: } \\
\hline City inequality & $\begin{array}{l}\text { Gini coefficient of the large city } \\
\text { districts by considering urban sample } \\
\text { persons of that districts. }\end{array}$ & $\begin{array}{l}\text { Unit level data of NSS 2004-05 on } \\
\text { consumer expenditure. }\end{array}$ \\
\hline City poverty rate & $\begin{array}{l}\text { Poverty head count ratio of the large } \\
\text { city districts by considering urban } \\
\text { sample persons of those districts. }\end{array}$ & $\begin{array}{l}\text { Unit level data of NSS 2004-05 on } \\
\text { consumer expenditure. }\end{array}$ \\
\hline \multicolumn{3}{|c|}{ Independent variables: } \\
\hline $\begin{array}{l}\text { Large city population } \\
\text { and its growth rate }\end{array}$ & $\begin{array}{l}52 \text { urban agglomerations with } \\
750,000 \text { or more inhabitants in } 2005 \\
\text { and growth rate of city population } \\
\text { over the period } 2000 \text { to } 2005 \text {. }\end{array}$ & $\begin{array}{l}\text { UN, World Urbanization Prospects, } \\
2009 \text { Revision. }\end{array}$ \\
\hline $\begin{array}{l}\text { Growth rate of city } \\
\text { population density }\end{array}$ & $\begin{array}{l}\text { Growth rate of city population density } \\
\text { over the period } 2000 \text { to } 2005 \text {. }\end{array}$ & $\begin{array}{l}\text { UN, World Urbanization Prospects, } \\
2009 \text { Revision and Town Directory, } \\
\text { Census of India 2001, GOI }\end{array}$ \\
\hline $\begin{array}{l}\text { City output and its } \\
\text { growth }\end{array}$ & $\begin{array}{l}\text { Per capita non-primary district } \\
\text { domestic product (DDP) is used to } \\
\text { measure the city output in 2004-05 } \\
\text { and growth rate of non- primary DDP } \\
\text { over the period } 2000-01 \text { to } 2004-05 \\
\text { at } 1999-2000 \text { constant prices, is } \\
\text { taken as a measure of urban } \\
\text { economic growth. }\end{array}$ & $\begin{array}{lcc}\text { Directorate of } & \text { Economics } & \text { and } \\
\text { Statistics (DES), } & \text { various } & \text { State } \\
\text { Governments, GOI. } & & \end{array}$ \\
\hline $\begin{array}{l}\text { Human } \\
\text { accumulation }\end{array}$ & $\begin{array}{l}\text { The effect of education which is } \\
\text { proxied by primary gross enrollment } \\
\text { ratio (Grades I-IV) and upper primary } \\
\text { gross enrollment ratio (Grades VI- } \\
\text { VIII) as of } 2005-06 \text { of the city district } \\
\text { and the city district literacy rate in } \\
2001 \text {. }\end{array}$ & $\begin{array}{l}\text { District Report Cards published by } \\
\text { National University of Educational } \\
\text { Planning and Administration (NUEPA), } \\
\text { New Delhi, and Census of India 2001. }\end{array}$ \\
\hline
\end{tabular}

Source: Author's compilation 


\subsection{Description of Data}

Appendix Table 7 presents the means, standard deviations, minimum, and maximum values for the sample used in regression analysis. Appendix Table 8 reports the sample correlation coefficients of the variables used in the regression analysis. The values of correlation coefficients show higher level of positive correlation between primary and upper primary gross enrollment ratio $(0.76)$, city population and city output $(0.52)$, city output and its growth rate $(0.37)$, and city population and city literacy rate (0.36). On the other hand, higher level of negative correlations are observed between city poverty rate and city output $(-0.37)$, city poverty rate and city population $(-0.31)$, and city inequality and primary gross enrollment ratio $(-0.17)$. However, the value of correlations ketween the independent variables does not show presence of multicollinearity. Most importantly, Appendix Figure 5 shows the 19 per cent positive correlation between logarithm of city population and city inequality. Appendix Figure 6 shows the 32 per cent negative correlation between city PHR and logarithm of city population.

Key proxy variables in the estimation include the following: (i) City district literacy as a proxy to the human capital accumulation, as literate people generally have a higher socio-economic status and employment prospects. (b) Primary and upper primary gross enrollment ratio as a second proxy variable of human capital accumulation, because high rate of enrollment in school makes faster growth in per capita income through rapid improvement in productivity (Bils and Klenow 2000). (c) Growth rate of city population density is used as a proxy of internal urban agglomeration as it associated with higher productivity. (d) Non- primary DDP as a proxy of city output as urban agglomeration manly indicates the agglomeration of manufacture and service sectors (Krugman 1991).

\subsection{Results of the estimation}

Table 4 summarizes the key results from the OLS regression estimation of determinants of urban inequality and poverty based on equation (1) and (2) with robust standard errors (to correct for heteroskedasticity) in parentheses. Urban inequality measured by city specific Gini coefficient values is the dependent variable for regression (1) and (2). On the other hand, urban poverty measured by dity specific poverty head count ratio is the dependent variable for regression (3), (4) and (5) for identifying determinants of urban poverty. The estimated models are different from one another due to specifications of variables used. Regression (1) and $\beta$ ) show the estimates of the full model which include all the independent variables, while regression (2), (4) and (5) report the results for a parsimonious model, excluding controls that are not found to be statistically significant in estimated models (1) and (3).

In regression (1), the result shows that log of city population has a positive and significant (at 5 per cent level) effect on log of city inequality. As two variables are in log form, the coefficient can be interpreted as elasticity. The finding supports the expected hypothesis and show that a 10 per cent increase in city population size increases city inequality by 0.7 per cent. This finding implies that large city population agglomeration increase in urban inequality goes together. On the contrary, a 10 per cent increase in city population growth rate (or growth rate of city population density) reduces urban inequality by 0.1 (or 0.4 ) per cent. This result runs counter to the expected hypothesis. However, both the coefficients turn out to be insignificant. The coefficient of DDP (or growth rate of DDP per capita) 
has a negative (or positive) significant effect on city inequality. The results suggest that with a 10 per cent increase in per capita DDP (or growth rate of DDP per capita) city inequality decreases (or increases) by 1.1 (or 22.7) per cent. The results imply that higher per capita income which captures average distribution of income reduces urban inequality, but higher economic growth increases urban inequality. This result locates urban India in the initial phase of Kuznet curve and suggests that higher economic growth is associated with higher inequality. The coefficient of poverty is 0.07 which implies that a 10 per cent increase in urban poverty increases urban inequality by 0.7 percent. As two variables are in log form the coefficient can be interpreted as elasticity. The coefficient is significant (at 10 per cent) and consistent with the expected sign. The coefficient of PGER is negative and significant which implies that with a 100 per cent increase in PGER, urban inequality decreases by almost 0.4 per cent. Nevertheless, UPGER and district literacy rate show a positive effect on city inequality even though the coefficients are not significant. The regression (1) explains 25 per ent of the total variation in the dependent variable.

Regression (2) reports estimate with a parsimonious set of controls. The regression results show that the effect of UPGER on urban inequality is positive as in regression (1), and is significant at 5 per cent level. This result implies that higher level of UPGER is associated with higher level of urban inequality. Moreover, the result also shows that the significance level of PGER variable increases from 10 per cent in regression (1) to 5 per cent in regression (2). In addition, the estimates of regression (2) provide consistent results for other variables that include DDP per capita, growth rate of DDP per capita, and city population, as the coefficients of these variables are showing equal level of significance and expected signs of regression (1). In addition, the coefficient of growth rate of city density has not shown any improvement from the earlier regression results in terms of level of significance. Overall, the explaining power of the model $\left(R^{2}\right)$ remains almost the same (about, 0.24$)$. 
Table 4: Determinants of Urban I nequality and Poverty

\begin{tabular}{|c|c|c|c|c|c|}
\hline \multirow{3}{*}{ I ndependent Variables } & \multicolumn{5}{|c|}{ Dependent Variables } \\
\hline & \multicolumn{2}{|c|}{ Log of Gini } & \multicolumn{3}{|c|}{ Log of Poverty Head Count Ratio } \\
\hline & (1) & (2) & (3) & (4) & (5) \\
\hline Constant & $\begin{array}{l}-0.942 \\
(0.568) \\
\end{array}$ & $\begin{array}{l}-0.788 \\
(0.518) \\
\end{array}$ & $\begin{array}{c}4.96^{* *} \\
(1.96) \\
\end{array}$ & $\begin{array}{l}5.68^{* *} \\
(2.16) \\
\end{array}$ & $\begin{array}{c}5.058^{* * *} \\
(1.36)\end{array}$ \\
\hline Log of DDP per capita & $\begin{array}{c}-0.111^{* *} \\
(0.044)\end{array}$ & $\begin{array}{c}-0.101^{* *} \\
(0.047)\end{array}$ & $\begin{array}{l}-0.004 \\
(0.228)\end{array}$ & $\begin{array}{l}-0.343^{*} \\
(0.199)\end{array}$ & \\
\hline $\begin{array}{l}\text { Growth rate of DDP per } \\
\text { capita }\end{array}$ & $\begin{array}{l}2.27^{*} \\
(1.2)\end{array}$ & $\begin{array}{l}2.26^{*} \\
(1.14)\end{array}$ & $\begin{array}{l}-6.14 \\
(3.68)\end{array}$ & & $\begin{array}{l}-5.65^{*} \\
(3.353)\end{array}$ \\
\hline Log of city population & $\begin{array}{l}0.068^{* *} \\
(0.032)\end{array}$ & $\begin{array}{l}0.069^{* *} \\
(0.032)\end{array}$ & $\begin{array}{l}-0.239^{*} \\
(0.122)\end{array}$ & & $\begin{array}{l}-0.215^{*} \\
(0.121)\end{array}$ \\
\hline PGER & $\begin{array}{l}-0.004^{*} \\
(0.002)\end{array}$ & $\begin{array}{c}-0.005^{* *} \\
(0.002)\end{array}$ & $\begin{array}{c}0.008 \\
(0.009)\end{array}$ & & $\begin{array}{c}0.011 \\
(0.008)\end{array}$ \\
\hline UPGER & $\begin{array}{c}0.003 \\
(0.002)\end{array}$ & $\begin{array}{l}0.004^{* *} \\
(0.002)\end{array}$ & $\begin{array}{l}-0.004 \\
(0.007)\end{array}$ & & $\begin{array}{l}-0.009 * \\
(.005)\end{array}$ \\
\hline District literacy rate & $\begin{array}{c}0.003 \\
(0.003)\end{array}$ & & $\begin{array}{l}-0.005 \\
(0.012)\end{array}$ & & \\
\hline $\begin{array}{l}\text { Log of city population } \\
\text { growth rate }\end{array}$ & $\begin{array}{l}-0.011 \\
(0.063)\end{array}$ & & $\begin{array}{l}23.81^{* *} \\
(10.64)\end{array}$ & $\begin{array}{c}22.65^{* *} \\
(9.47)\end{array}$ & \\
\hline $\begin{array}{l}\text { Log of growth rate of city } \\
\text { population density }\end{array}$ & $\begin{array}{l}-0.044 \\
(0.035)\end{array}$ & $\begin{array}{c}-0.04 \\
(0.035)\end{array}$ & $\begin{array}{c}0.163 \\
(0.215)\end{array}$ & & \\
\hline Log of Poverty & $\begin{array}{l}0.071^{*} \\
(0.039)\end{array}$ & $\begin{array}{l}0.066^{*} \\
(0.039)\end{array}$ & & & \\
\hline Log of Gini & & & $\begin{array}{l}0.701^{* *} \\
(0.335)\end{array}$ & $\begin{array}{c}0.051 \\
(0.342)\end{array}$ & $\begin{array}{l}0.688^{*} \\
(0.345)\end{array}$ \\
\hline No. of Obs. & 52 & 52 & 52 & 52 & 52 \\
\hline $\mathrm{R}^{2}$ & 0.25 & 0.24 & 0.39 & 0.21 & 0.29 \\
\hline
\end{tabular}

Note: Figures in parentheses represent robust standard errors. $* * *, * *$, and $*$ indicate statistical significance at $1 \%, 5 \%$ and $10 \%$ level respectively.

Source: Regression (1) and (2) are estimated using Equation (1). Regression (3), (4) and (5) are estimated using Equation (2).

Regression (3) shows that the elasticity (as the two variables are in log form) between city population and urban poverty is -0.24 implying that a 10 per cent increase in large city population causes a reduction in poverty by 2.4 per cent. The coefficient is significant (at 10 per cent) and has the expected sign. In contrast, city population growth has a significant (at 5 per cent level) negative effect on urban poverty. The result runs counter to the expected hypothesis. These results imply that though large population agglomeration reduces urban poverty, but over concentration (or higher population growth rate of a large city) increases urban poverty. The estimated coefficient of the urban inequality is positively and significantly related to urban poverty, which supports the predicted hypothesis. An increase of 10 per cent in the urban inequality leads to 7 per cent increase in the urban poverty. The coefficient $\delta$ DDP per capita (or growth rate of DDP per capita) is negative and insignificant. The coefficients of PGER, UPGER, district literacy rate, and growth rate of population density do not show significant effect on urban poverty. The regression explains 39 per cent of the total variation in the dependent variable.

Regression (4) shows that the DDP per capita has a significant negative effect on urban poverty which implies that higher per capita income leads to reduction (as expected) in urban poverty. The results also show that while the significance level of the coefficient of city population growth rate 
remains constant, the effect of urban inequality on urban poverty becomes insignificant. Most noticeably, the regression explains just 21 per cent of total variation in urban poverty across cities.

The coefficient of growth rate of DDP per capita in regression (5) is negative and has a significant (at the 10 per cent level) effect on urban poverty. The result supports the hypothesis of a negative impact of per capita income (or growth rate of DDP per capita) on urban poverty. Among the proxy variables considered to capture the human capital accumulation, UPGER shows a significant (at the 10 per cent level) and a negative (as expected) effect on urban poverty. However, PGER again remains statistically insignificant. In contrast, the significance level of the coefficient of urban inequality has improved to 10 per cent level from regression (4). Moreover, the $R^{2}$ shows a marginal increase to 0.29 .

\section{Major Conclusions and I mplications}

This paper is intended to explore the following two important issues: First, to quantify the level of city inequality and poverty by establishing an empirical link between them. Second, to estimate the determinants of urban inequality and poverty by using OLS regression estimation. For this analysis, individual-level data of NSS 2004-05 on consumer expenditure and city (or district) level data from various sources are used.

The study finds that by and large, cities with lower mean levels of per capita expenditure have higher headcount poverty rates and that mega cities unambiguously show lower poverty rate. The different size of cities at the aggregate level analysis shows that marginalized group (or other group) has lower level of inequality (or higher level of inequality) and higher level of poverty (or lower level of poverty). The decomposition of Gini index by the six Indian geographical urban zones shows that within-group (i.e., poor and non-poor group) inequality contributes higher than between-group inequality to inequality. The decomposition of FGT index (for alpha $=0$ ) by these six zones shows that more than 29 per cent of total poverty is attributable to the population group that lives in Northern zone.

OLS regression results suggest that large city population agglomeration, growth rate of city output, upper primary gross enrollment ratio and city poverty rate have a strong positive effect on city inequality. On the other hand, per capita city output and primary gross enrolment ratio have a strong (or robust) negative effect on city inequality. Moreover, level and growth rate of city output, large city population agglomeration and upper primary gross enrollment ratio have significant negative effect city poverty rate. On the contrary, large city population growth rate (capture over concentration) has a positive effect on city poverty rate.

The empirical analysis involving linking of urban inequality with poverty shows that redistributive policies would be more effective for quick poverty alleviation rather than for boosting the economy by increasing per capita GDP. It is because the average per capita monthly consumption expenditure is found to be relatively higher than the all-India urban poverty line in 200405. Most importantly, policy makers can use the decomposition results to formulate a workable poverty reduction policy. For instance, introduction of subsidy programmes for some goods that are largely consumed by poor households and a progressive income tax structure may result in significant reduction of total poverty in urban India. 
Finally, this paper argues that the Indian government needs to produce substantial city-level data on consumption and income for better analysis and policy prescription at sub-national or regional level for reduction of poverty and inequality. However, the estimation of poverty at city level using small area methodology and effects of urban economic growth on urban inequality and poverty in respect of different time periods are left for future research.

\section{Annexure I}

\section{Indicators of economic inequality and poverty and the link between them}

\section{Indicators of economic inequality}

\subsection{Gini Coefficient:}

let $x_{i}$ is the cumulated proportion of the population variable be a point on the $x$-axis, for $k=0, \ldots, n$, with $\mathrm{x}_{0}=0, \mathrm{x}_{\mathrm{n}}=1$.

Whereas, $y_{i}$ is the cumulated proportion of the income variable a point on the $y$-axis, for $k=0, \ldots, n$, with $\mathrm{y}_{0}=0, \mathrm{y}_{\mathrm{n}}=1$.

Then,

$$
\text { Gini }=1-\sum_{i=1}^{N}\left(x_{i}-x_{i-1}\right)\left(y_{i}+y_{i+1}\right)
$$

\section{J ackknife standard errors: (As given in Haughton and Khandker 2009)}

Suppose that we have a statistic, ? and we consider the static is Gini coefficient. For calculating its standard error we estimate the statistic which is $\hat{\theta}$, provided the statistic is not highly nonlinear. We could also estimate the statistic leaving out the $i$ th observation, representing it as $\hat{\boldsymbol{\theta}}_{(i)}$. If there are $\mathrm{N}$ observations in the sample, then the jackknife standard error of the statistic is given by

$$
s e=\left[(N-1 / N) \sum_{i=1}^{N}\left(\theta_{(i)}-\theta\right)^{2}\right]^{1 / 2}
$$

\section{Indicators of urban poverty}

2.1. Foster-Greer-Thorbecke (FGT) Index (Foster-Greer-Thorbecke 1984):

A generalized version of poverty indices was considered by Foster et al. (1984) as follows:

$$
\begin{aligned}
F G T=P_{\alpha}\left(x, x^{*}\right) & =\sum_{i=1}^{P}\left(\frac{1-x_{i}}{x^{*}}\right)^{\alpha} \\
& =\text { PR when } \alpha=0 \\
& =\text { PGR when } \alpha=1 \\
& =\text { SPGR when } \alpha=2
\end{aligned}
$$


$\mathrm{x}^{*}=$ poverty line; $\mathrm{x}_{\mathrm{i}}=$ monthly per capital consumption expenditure of $i$ th individual

$\mathrm{P}=$ number of persons with consumption expenditure less than $\mathrm{x}^{*}$.

\section{Measurement of poverty dominance:}

Distribution 1 dominates distribution 2 at order s over the range $\left[z^{-}, z^{+}\right]$if only if:

$P_{1}(\zeta ; \alpha)<P_{2}(\zeta ; \alpha) \quad \forall \quad \zeta \in\left[\mathrm{Z}^{-}, Z^{+}\right]$for $\alpha=$ s-1

\section{The link between Poverty and Inequality: (As given in Ararr and Timothy} 2006)

\subsection{Poverty indices and inequality}

Poverty indices can be decomposed as follows:

$P(y, z)=E_{\mu}+E_{\pi}$

Where $y$ represents the vector of incomes, $z$ is the poverty line, 4 is the contribution of average income $(\mu)$ with perfect equality and $E_{\Pi}$ is the contribution of total inequality $\Pi$ ) with the observed average income. Formally, as in Ararr and Timothy (2006), the contribution of average income can be written as:

$$
\begin{aligned}
\mathrm{E}_{\mu / \Pi=0} & =0, & & \text { when } \mu>\mathrm{z} \\
& =\mathrm{P}(\mu, \mathrm{z}), & & \text { when } \mu<\mathrm{z}
\end{aligned}
$$

\subsection{Gini index Lorenz curve and poverty}

To represent overall inequality the Lorenz is a useful tool. As shown by Datt and Ravallion (1992), the link between the headcount, noted by $\mathrm{H}$, and the Lorenz curve is:

$$
L^{\prime}(H)=\frac{Z}{\mu}
$$

Where $Z$ and $\mu$ stand for poverty line and average income, respectively.

The link between the average poverty gap, denoted by $\mathrm{P}_{1}$, and inequality represented by the Lorenz curve is:

$$
P_{1}=\left[Z-\mu_{P}\right] H
$$

where $\mu_{p}$ is the average income of the poor group. The ink between the severity index, represented by the square of the poverty gap, and the Lorenz curve can be written as:

$$
P_{2}=\int_{0}^{H}\left[\begin{array}{ll}
Z & -\mu \\
L^{\prime} & (p)
\end{array}\right]^{2} d p
$$

As shown by Ararr and Timothy (2006), the decomposition of the Gini index can be written in the following form:

$$
I=\varphi_{p} \psi_{p} I_{p}+\varphi_{n p} \psi_{n p}+\tilde{\mathrm{I}}
$$


where $\mathrm{I}$ is the Gini index, $\mathrm{Fg}$ and ? $g$ are the population and income shares for the group $g$ respectively and $I$ is the Gini index where within-group inequality is eliminated, i.e., each household have average income of its group. Based on this, the link between headcount index and the between-group inequality is as follows:

$$
H=\mu \tilde{\mathrm{I}}\left(\frac{1}{\mu-\mu p}\right)
$$

Then they find that the component between-group inequality can be expressed as follows:

$$
\tilde{\mathrm{I}}=H-L(H)
$$

where $L(H)$ is the level of Lorenz curve when the percentile $p=H$.

For the poverty gap index, the link can be expressed as follows:

$$
P_{1}=\mu \tilde{\mathrm{I}}\left(\frac{Z-\mu_{p}}{\mu-\mu p}\right)
$$

\subsection{Population Groups, I nequality and Poverty}

To find out the contribution of regional disparities to the total poverty and to estimate the contribution of the within-group inequality of a given group to total poverty, an excellent decomposition method has been proposed by Ararr and Timothy (2006), which takes the following form.

$$
P(y, z)=E_{\mu}+E_{B}+\sum_{g=1}^{G} E_{W}^{g}
$$

Where

$$
E_{W}^{g}=0.5 \phi_{g}\left[P_{g}(y)-P_{g}\left(y\left(\mu / \mu_{g}\right)\right)+P_{g}\left(\mu_{g}\right)-P_{g}(\mu)\right]
$$

where $\mathrm{E}_{\mathrm{B}}$ is the contribution of the between-group inequality and $E_{w}^{g}$ is the contribution of inequality within the group g. 


\section{Appendix Table 1: Name of theDistricts Used in the Regression Analysis}

Agra $(\text { Agra })^{1}$, Aligarh (Aligarh), Allahabad (Allahabad) ${ }^{1}$, Amritsar (Amritsar) ${ }^{1}$, Barddhaman (Asansol) ${ }^{1}$, Aurangabad (Aurangabad), Bangalore Urban (Bangalore)1, Bareilly (Bareilly), Thane (Bhiwandi), Bhopal (Bhopal) ${ }^{1}$, Khordha (Bhubaneswar), Chandigarh*, Chennai (Chennai) ${ }^{1}$, Coimbatore (Coimbatore) ${ }^{1}$, Delhi* ${ }^{1}$, Dhanbad (Dhanbad) ${ }^{1}$, Durg (Durg-Bhilainagar), Kamrup (Guwahati), Gwalior (Gwalior), Dharward (Hubli-Dharwad), Hyderabad (Hyderabad) ${ }^{1}$, Indore (Indore) ${ }^{1}$, Jabalpur (Jabalpur), Jaipur (Jaipur) ${ }^{1}$, Jalandhar (Jalandhar) ${ }^{1}$, Purbi Singhbhum (Jamshedpur) ${ }^{1}$, Jodhpur (J odhpur), Kanpur Nagar (Kanpur) ${ }^{1}$, Eranakulam (Kochi) ${ }^{1}$, Kolkata (Kolkata) ${ }^{1}$, Kota (Kota), Kozhikode (Kozhikode), Lucknow (Lucknow) ${ }^{1}$, Ludhiana (Ludhiana) ${ }^{1}$, Madurai (Madurai) ${ }^{1}$, Meerut (Meerut) ${ }^{1}$, Moradabad (Moradabad), Mumbai (Mumbai) ${ }^{1}$, Mysore (Mysore), Nagpur (Nagpur) ${ }^{1}$, Nashik (Nashik) ${ }^{1}$, Patna (Patna) ${ }^{1}$, Pune (Pune) ${ }^{1}$, Raipur (Raipur), Ranchi (Ranchi), Salem (Salem), Solapur (Solapur), Thiruvananthapuram (Thiruvananthapuram), Tiruchirappalli (Tiruchirappalli), Varanasi (Varanasi) ${ }^{1}$, Krishna (Vijayawada) ${ }^{1}$, Visakhapatnam (Visakhapatnam) ${ }^{1}$

* Delhi and Chandigarh were considered as a whole proxy of a city district.

1 Indicates metropolitan cities.

Notes: Name in the first bracket indicates the name of the city which is located in the corresponding district.

Appendix Table 2: Calculated Values of I nequality and Poverty I ndicesat

District Level - Urban

\begin{tabular}{|c|c|c|c|c|c|c|c|c|c|c|}
\hline \multirow{3}{*}{$\begin{array}{l}\text { Sr. } \\
\text { No. }\end{array}$} & \multirow{3}{*}{$\begin{array}{l}\text { Name of the } \\
\text { Districts }\end{array}$} & \multicolumn{4}{|c|}{ Urban I nequality } & \multicolumn{4}{|c|}{ Urban Poverty } & \multirow[b]{3}{*}{$\begin{array}{l}\text { Mean } \\
\text { MPCE } \\
\end{array}$} \\
\hline & & \multirow{2}{*}{ Gini } & \multirow{2}{*}{$\begin{array}{l}\text { Standard } \\
\text { error }\end{array}$} & \multicolumn{2}{|c|}{$\begin{array}{c}95 \% \\
\text { confidence } \\
\text { interval }\end{array}$} & \multirow{2}{*}{$\begin{array}{c}\text { State } \\
\text { Urban } \\
\text { Poverty } \\
\text { Lines } \\
\text { (2004- } \\
\text { 05) }\end{array}$} & \multirow{2}{*}{$\begin{array}{l}\text { FGT } \\
(0)\end{array}$} & \multirow{2}{*}{$\begin{array}{l}\text { FGT } \\
(1)\end{array}$} & \multirow{2}{*}{$\begin{array}{l}\text { FGT } \\
(2)\end{array}$} & \\
\hline & & & & $\begin{array}{l}\text { Lower } \\
\text { bound }\end{array}$ & $\begin{array}{l}\text { Upper } \\
\text { bound }\end{array}$ & & & & & \\
\hline 1 & Agra & 0.514 & 0.028 & 0.46 & 0.568 & 532.12 & 27.6 & 7.4 & 2.3 & 1393 \\
\hline 2 & Aligarh & 0.276 & 0.015 & 0.246 & 0.305 & 532.12 & 29.7 & 6 & 2.1 & 784 \\
\hline 3 & Allahabad & 0.316 & 0.021 & 0.274 & 0.358 & 532.12 & 41.8 & 9.2 & 2.8 & 731 \\
\hline 4 & Amrithar & 0.226 & 0.005 & 0.216 & 0.237 & 642.51 & 17.5 & 2.4 & 0.5 & 917 \\
\hline 5 & Aurangabad & 0.388 & 0.022 & 0.345 & 0.431 & 631.85 & 63.8 & 20.7 & 8.1 & 688 \\
\hline 6 & Bangalore & 0.329 & 0.008 & 0.313 & 0.346 & 588.06 & 2.6 & 0.4 & 0.1 & 1395 \\
\hline 7 & Barddhaman & 0.334 & 0.008 & 0.319 & 0.348 & 572.51 & 38.1 & 9.2 & 2.9 & 824 \\
\hline 8 & Bareilly & 0.389 & 0.02 & 0.35 & 0.428 & 532.12 & 21.6 & 4.5 & 1.5 & 1121 \\
\hline 9 & Bhopal & 0.3 & 0.009 & 0.282 & 0.318 & 532.26 & 23.4 & 4.7 & 1.3 & 856 \\
\hline 10 & Chandigarh & 0.36 & 0.009 & 0.344 & 0.377 & 634.46 & 10.1 & 2.1 & 0.6 & 1770 \\
\hline 11 & Chennai & 0.37 & 0.009 & 0.353 & 0.387 & 559.77 & 7.5 & 1.1 & 0.2 & 1596 \\
\hline 12 & Coimbatore & 0.354 & 0.014 & 0.327 & 0.381 & 559.77 & 17.1 & 2.9 & 0.8 & 1085 \\
\hline 13 & Delhi State & 0.336 & 0.005 & 0.326 & 0.347 & 642.47 & 12.9 & 2 & 0.5 & 1319 \\
\hline 14 & Dhanbad & 0.388 & 0.02 & 0.348 & 0.428 & 531.35 & 24.8 & 4.6 & 1.1 & 1065 \\
\hline 15 & Dharward & 0.393 & 0.031 & 0.331 & 0.454 & 588.06 & 32.1 & 6.3 & 2.3 & 1083 \\
\hline
\end{tabular}




\begin{tabular}{|c|c|c|c|c|c|c|c|c|c|c|}
\hline 16 & Durg & 0.498 & 0.065 & 0.371 & 0.626 & 513.7 & 16.5 & 2.2 & 0.4 & 1310 \\
\hline 17 & Ernakulam & 0.401 & 0.018 & 0.366 & 0.436 & 584.7 & 14 & 1.9 & 0.4 & 1419 \\
\hline 18 & Greater Mumbai & 0.371 & 0.007 & 0.357 & 0.386 & 631.85 & 6.3 & 1 & 0.2 & 1570 \\
\hline 19 & Gwalior & 0.414 & 0.023 & 0.369 & 0.46 & 532.26 & 36.3 & 7.7 & 2.4 & 941 \\
\hline 20 & Hyderabad & 0.433 & 0.027 & 0.381 & 0.485 & 563.16 & 15.3 & 2.9 & 0.7 & 1296 \\
\hline 21 & Indore & 0.454 & 0.036 & 0.382 & 0.525 & 532.26 & 18.2 & 3.5 & 1 & 1648 \\
\hline 22 & Jabalpur & 0.293 & 0.012 & 0.27 & 0.316 & 532.26 & 18.7 & 4.3 & 1.6 & 871 \\
\hline 23 & Jaipur & 0.481 & 0.044 & 0.395 & 0.567 & 568.15 & 35.7 & 6.5 & 1.8 & 1147 \\
\hline 24 & Jalandhar & 0.286 & 0.01 & 0.267 & 0.305 & 642.51 & 16.4 & 2 & 0.4 & 1170 \\
\hline 25 & Jodhpur & 0.302 & 0.017 & 0.269 & 0.335 & 568.15 & 12.6 & 1.3 & 0.2 & 1073 \\
\hline 26 & Kamrup & 0.273 & 0.016 & 0.243 & 0.304 & 600.03 & 11.3 & 2.5 & 0.9 & 1272 \\
\hline 27 & Kanpur Nagar & 0.399 & 0.021 & 0.358 & 0.44 & 532.12 & 15.8 & 3.2 & 0.9 & 1224 \\
\hline 28 & Khordha & 0.401 & 0.017 & 0.367 & 0.434 & 497.31 & 45.3 & 11.6 & 4.8 & 809 \\
\hline 29 & Kolkata & 0.403 & 0.012 & 0.379 & 0.427 & 572.51 & 8.3 & 1.2 & 0.3 & 1520 \\
\hline 30 & Kota & 0.355 & 0.021 & 0.315 & 0.395 & 568.15 & 6.4 & 1.4 & 0.3 & 1477 \\
\hline 31 & Kozhikode & 0.368 & 0.016 & 0.337 & 0.399 & 584.7 & 31.3 & 8.8 & 3.3 & 918 \\
\hline 32 & Krishna & 0.329 & 0.016 & 0.298 & 0.36 & 563.16 & 13.9 & 2.7 & 0.7 & 793 \\
\hline 33 & Lucknow & 0.437 & 0.014 & 0.41 & 0.463 & 532.12 & 11.4 & 2.3 & 0.9 & 1329 \\
\hline 34 & Ludhiana & 0.523 & 0.086 & 0.353 & 0.692 & 642.51 & 16.7 & 2.6 & 0.6 & 1835 \\
\hline 35 & Madurai & 0.286 & 0.011 & 0.264 & 0.307 & 559.77 & 14.2 & 2.5 & 0.7 & 1025 \\
\hline 36 & Meerut & 0.281 & 0.012 & 0.256 & 0.305 & 532.12 & 15.4 & 3.2 & 0.9 & 897 \\
\hline 37 & Moradabad & 0.308 & 0.01 & 0.289 & 0.326 & 532.12 & 25.9 & 3.4 & 0.9 & 952 \\
\hline 38 & Mysore & 0.297 & 0.014 & 0.27 & 0.324 & 588.06 & 18.6 & 3.9 & 1.4 & 1046 \\
\hline 39 & Nagpur & 0.395 & 0.023 & 0.35 & 0.44 & 631.85 & 30.3 & 8.1 & 3 & 1078 \\
\hline 40 & Nashik & 0.367 & 0.008 & 0.352 & 0.382 & 631.85 & 54.3 & 16.1 & 7 & 875 \\
\hline 41 & Patna & 0.352 & 0.023 & 0.307 & 0.398 & 526.18 & 27 & 7 & 2.1 & 908 \\
\hline 42 & Pune & 0.325 & 0.007 & 0.311 & 0.339 & 631.85 & 19.5 & 3 & 0.7 & 1177 \\
\hline 43 & Purbi-Singhbhum & 0.309 & 0.014 & 0.281 & 0.337 & 531.35 & 13.4 & 3.2 & 1 & 1212 \\
\hline 44 & Raipur & 0.377 & 0.024 & 0.33 & 0.424 & 513.7 & 24.6 & 7.3 & 2.9 & 835 \\
\hline 45 & Ranchi & 0.299 & 0.013 & 0.273 & 0.325 & 531.35 & 21 & 5.7 & 1.9 & 799 \\
\hline 46 & Salem & 0.379 & 0.015 & 0.349 & 0.408 & 559.77 & 27.6 & 7.2 & 2.7 & 965 \\
\hline 47 & Solapur & 0.288 & 0.009 & 0.271 & 0.304 & 631.85 & 44.8 & 11.8 & 4.2 & 735 \\
\hline 48 & Thane & 0.327 & 0.008 & 0.311 & 0.343 & 631.85 & 10 & 1.9 & 0.5 & 1281 \\
\hline 49 & Thiruvananthapuram & 0.391 & 0.021 & 0.351 & 0.431 & 584.7 & 4.7 & 0.9 & 0.3 & 1867 \\
\hline 50 & Tiruchirappalli & 0.321 & 0.011 & 0.298 & 0.343 & 559.77 & 16.3 & 2.3 & 0.6 & 1111 \\
\hline 51 & Varanasi & 0.322 & 0.021 & 0.282 & 0.363 & 532.12 & 20.6 & 4.5 & 1.5 & 837 \\
\hline 52 & Visakhapatnam & 0.467 & 0.019 & 0.43 & 0.504 & 563.16 & 9.6 & 1.8 & 0.6 & 1734 \\
\hline
\end{tabular}

Note: 1 . The average of the poverty line of Punjab and Haryana is considered asChandigarh's poverty line.

2. Mean MPCE based on 30-day recall or reference period.

Source:Author's calculation using NSS $61^{\text {st }}$ Round unit level data of National Sample Survey of 2004-05 in consumer expenditure. 
Appendix Figure 1: Poverty dominance curve for six mega city districts

CDFs for Bangalore and other urban regions of Karnata

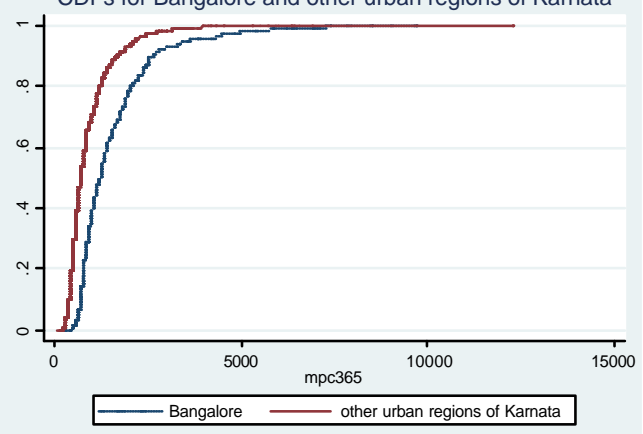

CDFs for Kolkata and other urban regions of West Bengal

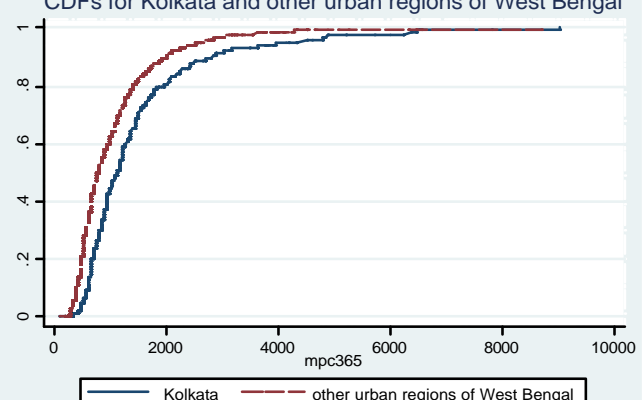

CDFs for Mumbai and other urban regions of Maharashtra

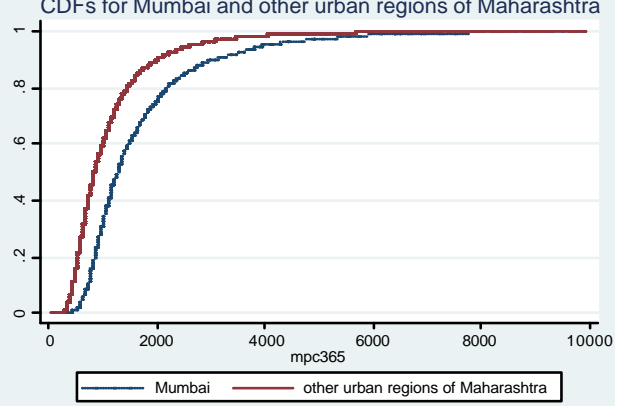

CDFs for Chennai and other urban regions of Tamil Nadu

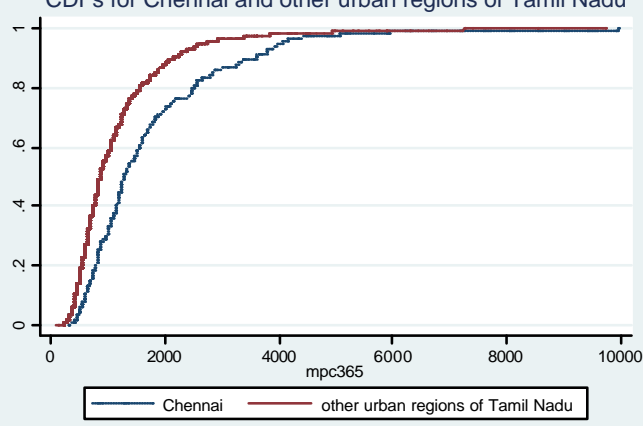

CDFs for Hyderabad and other urban regions of Andhra Pradesh

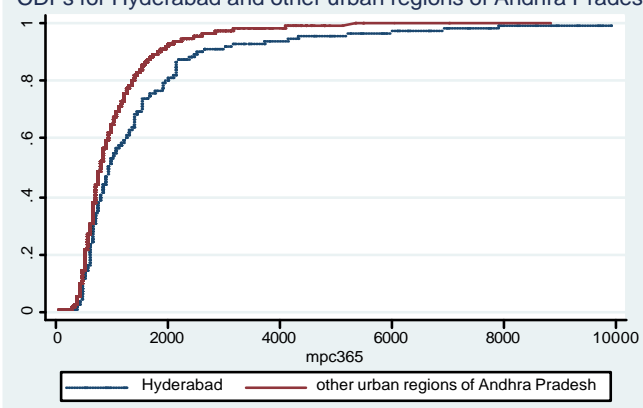

CDFs for Delhi and other urban regions of Delhi State

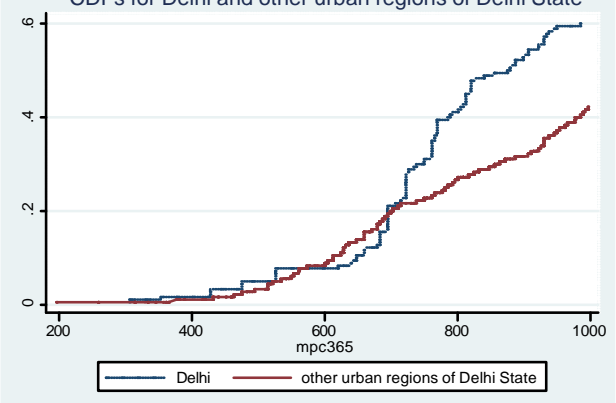

Source:Author's calculation using STATA 11 and individual level data from NSS $61^{\text {st }}$ Round on consumption expenditure survey. 
Appendix Table 3: Decomposition of the FGT index according to the geopoltical zones.

$$
\text { ( } a=0 ; z=578.8 \text { Rupees) }
$$

\begin{tabular}{|l|c|c|c|c|}
\hline \multicolumn{1}{|c|}{ Group } & FGT Index & $\begin{array}{c}\text { Population } \\
\text { Share }\end{array}$ & $\begin{array}{c}\text { Absolute } \\
\text { Contribution }\end{array}$ & $\begin{array}{c}\text { Relative } \\
\text { Contribution }\end{array}$ \\
\hline North & 0.332954 & 0.2722 & 0.090642 & 0.288562 \\
\hline North-East & 0.202630 & 0.015123 & 0.003064 & 0.009756 \\
\hline West & 0.246889 & 0.272224 & 0.067209 & 0.213962 \\
\hline South & 0.274732 & 0.222792 & 0.061208 & 0.194857 \\
\hline East & 0.406335 & 0.141072 & 0.057322 & 0.182487 \\
\hline Central & 0.452903 & 0.076552 & 0.034671 & 0.110375 \\
\hline Total & $\mathbf{0 . 3 1 4 1 1 7}$ & $\mathbf{1 . 0 0 0 0 0 0}$ & $\mathbf{0 . 3 1 4 1 1 7}$ & $\mathbf{1 . 0 0 0 0 0 0}$ \\
\hline
\end{tabular}

Source: Author's calculation using DASP software and NSS $61^{\text {st }}$ Round unit level data of National Sample Survey in 2004-05 on consumer expenditure.

\section{Appendix Figure 2: Lorenz curve, Gini index and poverty- Urban India (2004-05)}

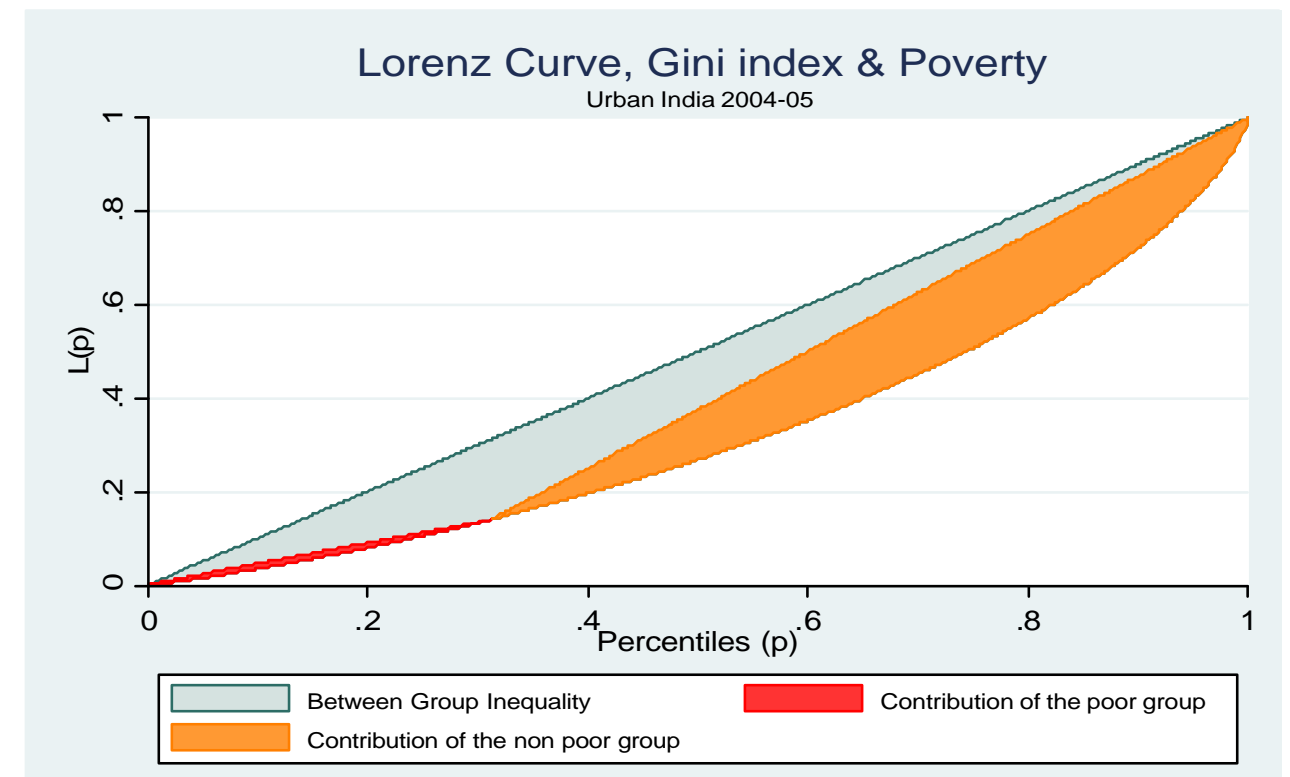

Source:Drawn by author using DASP software and NSS $61^{\text {st }}$ Round unit level data of National Sample Survey in 2004-05 on consumer expenditure. 
Appendix Table 4: Decomposition of the Gini index according to the geopolitical zones

\begin{tabular}{|l|c|c|c|c|c|}
\hline Group & Gini I ndex & $\begin{array}{c}\text { Population } \\
\text { Share }\end{array}$ & $\begin{array}{c}\text { Income } \\
\text { Share }\end{array}$ & $\begin{array}{c}\text { Absolute } \\
\text { Contribution }\end{array}$ & $\begin{array}{c}\text { Relative } \\
\text { Contribution }\end{array}$ \\
\hline North & 0.3486 & 0.2722 & 0.2642 & 0.0251 & 0.0722 \\
\hline North-East & 0.2852 & 0.0151 & 0.0161 & 0.0001 & 0.0002 \\
\hline West & 0.3329 & 0.2722 & 0.2901 & 0.0263 & 0.0757 \\
\hline South & 0.3507 & 0.2228 & 0.2380 & 0.0186 & 0.0535 \\
\hline East & 0.3551 & 0.1411 & 0.1282 & 0.0064 & 0.0185 \\
\hline Central & 0.3464 & 0.0766 & 0.0634 & 0.0017 & 0.0048 \\
\hline Within group & - & - & - & 0.0781 & 0.2250 \\
\hline Between group & - & - & - & 0.0404 & 0.1163 \\
\hline Overlap (residue) & - & - & - & 0.2288 & 0.6587 \\
\hline Total & $\mathbf{0 . 3 4 7 3}$ & $\mathbf{1 . 0 0 0 0}$ & $\mathbf{1 . 0 0 0 0}$ & $\mathbf{0 . 3 4 7 3}$ & $\mathbf{1 . 0 0 0 0}$ \\
\hline
\end{tabular}

Source:Author's calculation using DASP software and NSS $61^{\text {st }}$ Round unit level data of National Sample Survey in 2004-05 on consumer expenditure.

Appendix Figure 3: Contribution of the average expenditure and inequality and components to the total poverty (FGT $(a=0)$ )

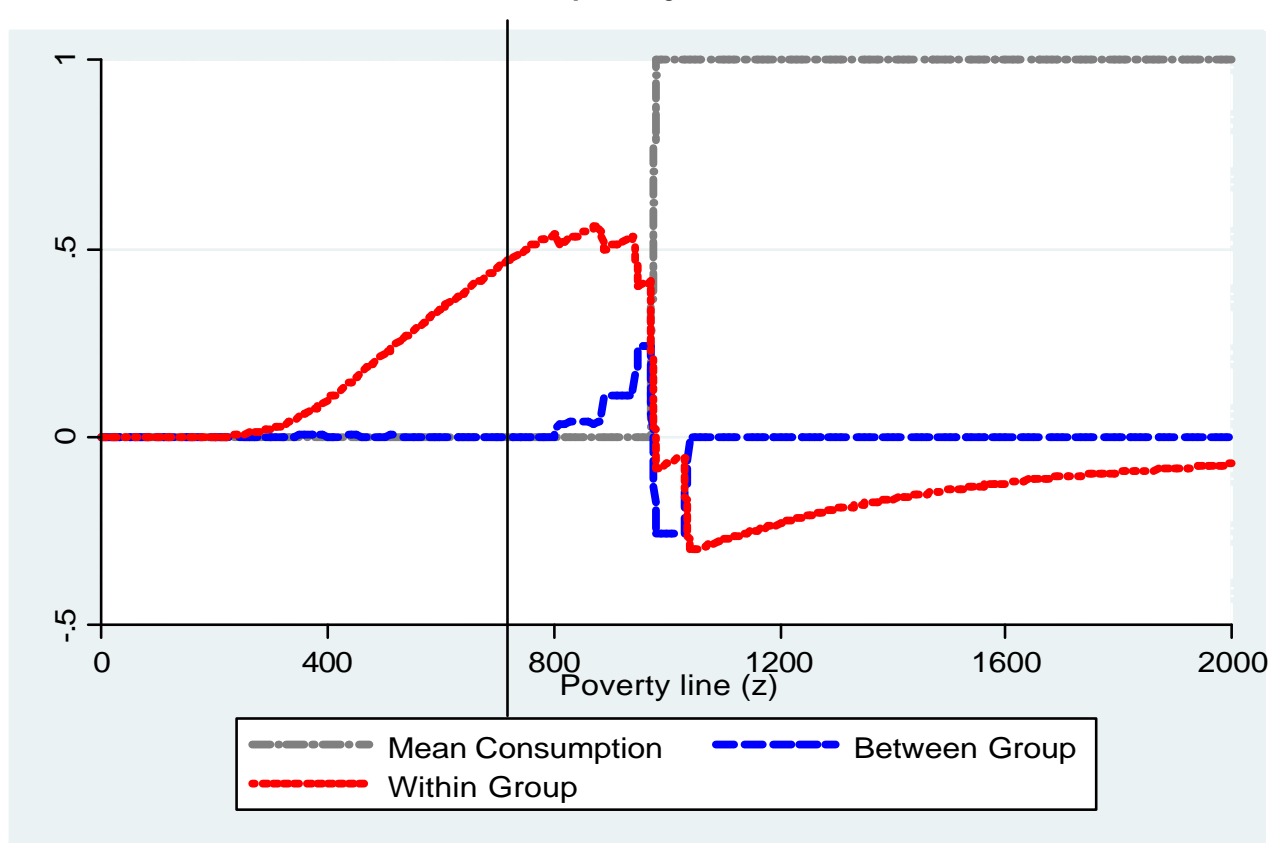

Source:Drawn by author using DASP software and NSS $61^{\text {st }}$ Round unit level data of National Sample Survey in 2004-05 of consumer expenditure. 
Appendix Figure 4: Contribution of the average expenditure and inequality and components to the total poverty $(\mathrm{FGT}(\mathrm{a}=1)$ ).

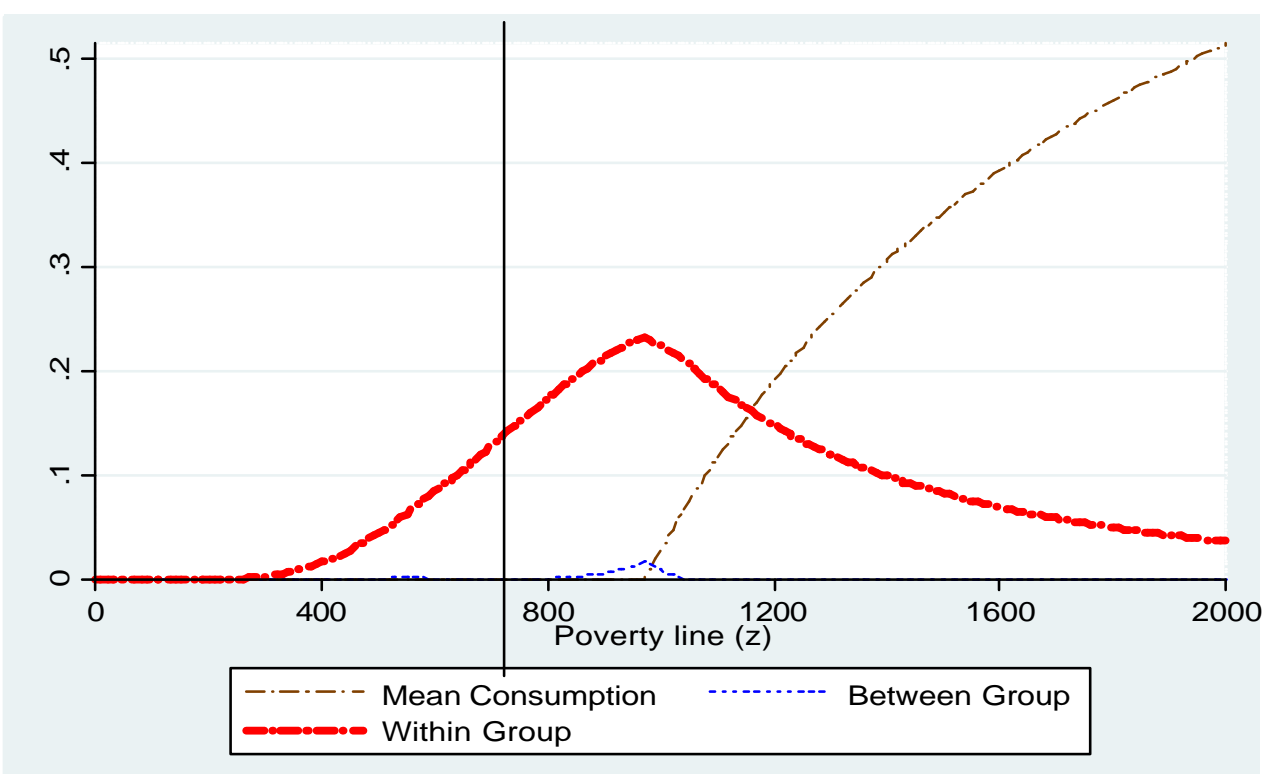

Source:Drawn by author using DASP software and NSS $61^{\text {st }}$ Round unit level data of National Sample Survey in 2004-05 on consumer expenditure.

Appendix Table 5: Decomposing the FGT index $(\alpha=0)$ by average expenditure and inequality components

\begin{tabular}{|l|c|c|c|}
\hline \multirow{2}{*}{ Components } & \multicolumn{3}{|c|}{ Poverty line = Rs. 578.8 } \\
\cline { 2 - 4 } & Absolute Contribution & $\begin{array}{c}\text { Relative } \\
\text { Contribution }\end{array}$ & Population Share \\
\hline North & 0.088143 & 0.280644 & 0.272237 \\
\hline North-East & 0.003283 & 0.010454 & 0.015123 \\
\hline West & 0.073797 & 0.234968 & 0.272224 \\
\hline South & 0.066040 & 0.210269 & 0.222792 \\
\hline East & 0.053325 & 0.169785 & 0.141072 \\
\hline Central & 0.029485 & 0.093880 & 0.076552 \\
\hline Within Group & 0.314073 & 0.999859 & 1.00000 \\
\hline Between Group & 0.000044 & 0.000141 & - \\
\hline Average income & 0.000000 & 0.000000 & - \\
\hline Total & $\mathbf{0 . 3 1 4 1 1 7}$ & $\mathbf{1 . 0 0 0 0 0 0}$ & $\mathbf{1 . 0 0 0 0 0 0}$ \\
\hline
\end{tabular}

Source:Author's calculation using DASP software and NSS $61^{\text {st }}$ Round unit level data of National Sample Survey in 2004-05 on consumer expenditure. 
Appendix Table 6: Decomposing the FGT index $(\mathrm{a}=1)$ by average expenditure and inequality components

\begin{tabular}{|l|c|c|c|}
\hline \multirow{2}{*}{ Components } & \multicolumn{3}{|c|}{ Poverty line = Rs. 578.8 } \\
\cline { 2 - 4 } & $\begin{array}{c}\text { Absolute } \\
\text { Contribution }\end{array}$ & $\begin{array}{c}\text { Relative } \\
\text { Contribution }\end{array}$ & Population Share \\
\hline North & 0.021709 & 0.287231 & 0.272237 \\
\hline North-East & 0.000605 & 0.008006 & 0.015123 \\
\hline West & 0.016568 & 0.219213 & 0.272224 \\
\hline South & 0.015381 & 0.203508 & 0.222792 \\
\hline East & 0.013660 & 0.180738 & 0.141072 \\
\hline Central & 0.007657 & 0.101304 & 0.076552 \\
\hline Within Group & 0.075580 & 0.982362 & 1.000000 \\
\hline Between Group & 0.001357 & 0.017638 & - \\
\hline Average income & 0.000000 & 0.000000 & - \\
\hline Total & $\mathbf{0 . 0 7 6 9 3 7}$ & $\mathbf{1 . 0 0 0 0 0 0}$ & $\mathbf{1 . 0 0 0 0 0 0}$ \\
\hline
\end{tabular}

Source: Author's calculation using DASP software and NSS $61^{\text {st }}$ Round unit level data of National Sample Survey in 2004-05 on consumer expenditure.

Appendix Table 7: Descriptive Statistics

\begin{tabular}{|l|c|c|c|c|}
\hline & Mean & $\begin{array}{c}\text { Standard } \\
\text { Deviation }\end{array}$ & Minimum & Maximum \\
\hline Gini coefficient (GC) & 0.36 & 0.07 & 0.23 & 0.52 \\
\hline Poverty head count ratio (PHCR) & 21.52 & 12.78 & 2.6 & 63.8 \\
\hline City population in thousands (CP) & 2553.48 & 3980.36 & 744 & 19493 \\
\hline City population growth (CPG) & 0.028 & 0.009 & 0.009 & 0.044 \\
\hline Growth rate of city density (CPDG) & 0.21 & 0.27 & 0.04 & 1.44 \\
\hline Per capita city output in thousand Rs. (CY) & 21.34 & 11.73 & 0.79 & 66.82 \\
\hline Growth of per capita city output (GCY) & 0.051 & 0.028 & -0.001 & 0.13 \\
\hline Primary gross enrollment ratio (PGER) & 71.34 & 23.92 & 0 & 114.5 \\
\hline $\begin{array}{l}\text { Upper primary gross enrollment ratio } \\
\text { (UPGER) }\end{array}$ & 45.03 & 23.58 & 0 & 98.1 \\
\hline District literacy rate in \% (DLR) & 72.67 & 9.93 & 44.75 & 93.2 \\
\hline
\end{tabular}

Source:Author's Computation 
Appendix Table 8: Correlations between dependent and independent variables

\begin{tabular}{lcccccccccc}
\hline & GC & PHCR & CY & GCY & CP & PGER & UPGER & DLR & CPG & CPDG \\
\hline GC & 1 & & & & & & & & & \\
PHCR & 0.06 & 1 & & & & & & & & \\
CY & 0.00 & -0.37 & 1 & & & & & & \\
GCY & 0.08 & -0.13 & 0.37 & 1 & & & & & \\
CP & 0.08 & -0.31 & 0.52 & 0.09 & 1 & & & & \\
PGER & -0.17 & 0.16 & -0.23 & -0.05 & -0.28 & 1 & & & & \\
UPGER & -0.01 & -0.06 & 0.1 & -0.06 & -0.01 & 0.76 & 1 & & & \\
DLR & 0.13 & -0.22 & 0.6 & 0.19 & 0.36 & -0.15 & 0.23 & 1 & & \\
CPG & 0.05 & 0.33 & 0.14 & 0.1 & 0.06 & -0.15 & -0.28 & -0.14 & 1 & \\
CPDG & -0.04 & -0.14 & 0.23 & 0.24 & 0.23 & -0.16 & -0.07 & 0.17 & -0.01 & 1 \\
\hline
\end{tabular}

Note: See Appendix Table 11 for variable definitions.

Source:Author's calculations

\section{Appendix Figure 5}

Relationship between the Gini Coefficient and Log of City Population, 2005

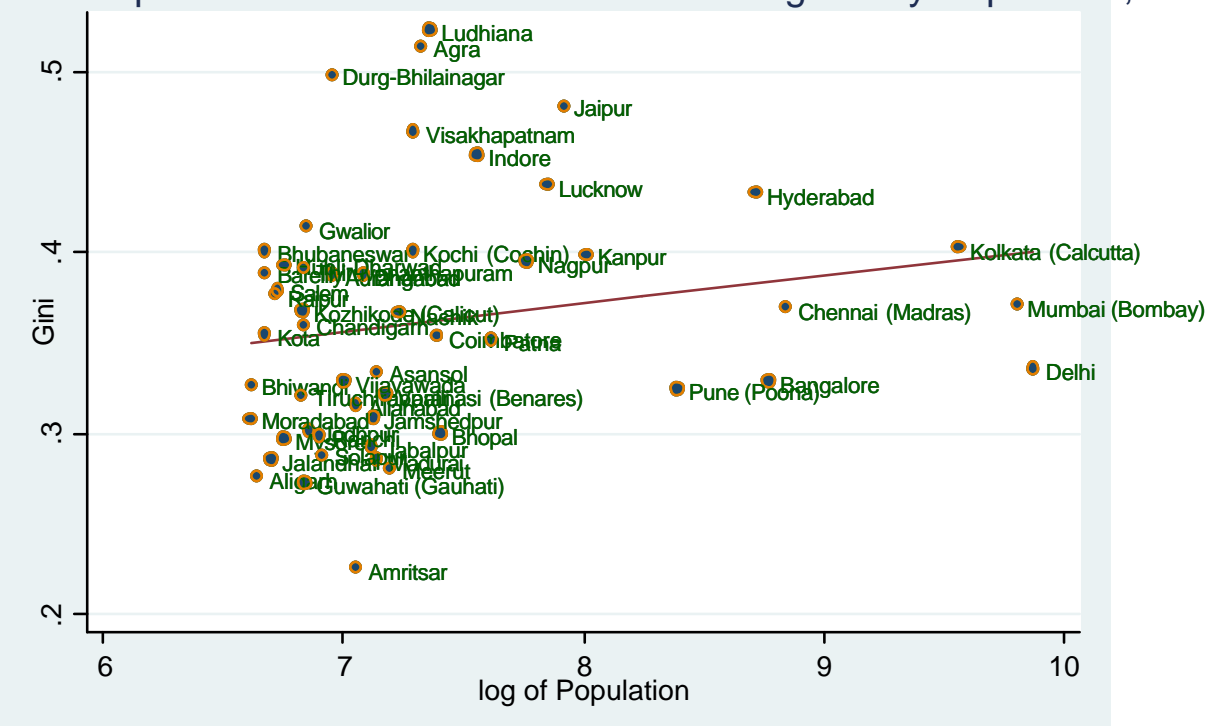

Source:Author 


\section{Appendix Figure 6}

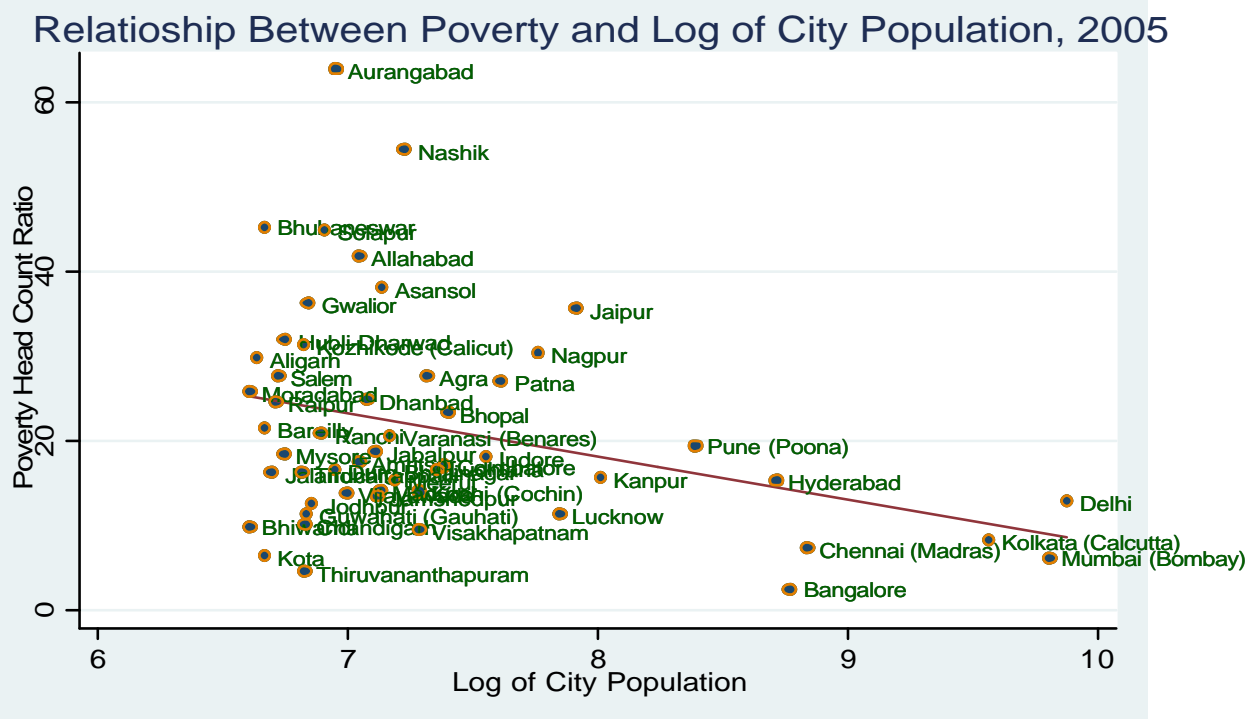

Source:Author

\section{Notes}

1 Jackknife estimate provides satisfactory approximation for estimation of Gini coefficient (where analytical standard errors may not exist).

2 City district means the district in which the city is located.

3 The Uniform Recall Period refers to consumption expenditure data collected using the 30 day recall or reference period. The Mixed Recall Period refers to consumption expenditure data collected using the oneyear recall period for five non-food items (i.e., clothing, footwear, durable goods, education and institutional medical expenses) and 30-day recall period for the rest of items.

4 Tendulkar's committee recommended methodology for poverty estimation is now a controversial issue in India and Govt. of India has set up a Technical Group (Planning Commission Press Release on 24 May, 2012) to revisit the methodology for estimation of poverty and identification of the poor under the chairmanship of $\operatorname{Dr} C$ Rangarajan, which is now on going.

5 Survey data of several agencies have clearly brought out that prices of commodities and services vary significantly across different size class of cities/towns (see for detailed explanation Kundu and Sarangi, 2005).

6 Sampling weights are used to derive population level for all the estimates.

7 The URP distribution of MPCE has more extreme MPCE values than MRP which results higher values of inequality measures. As per the NSS report on "Level and Pattern of Consumer Expenditure, 2004-05", the Lorenz ratios for urban India is 0.37 (or 0.36) for MPCE based on URP (or MRP).

8 In order to compute different poverty indices, whole Delhi is considered a proxy of Delhi city, but for comparing poverty dominance, North-West Delhi district is considered a proxy of Delhi city and compared with rest of Delhi.

9 The overlap is implied when the income of the richer person in group $i$ is higher than that of the poorer person in group j (see for details explanation in Araar 2006). 
10 The relationship between economic growth, inequality and poverty is complex, non-linear, and follows a dynamic process. Kuznet (1955) examined the link between poverty, inequality and growth and found an inverted U shape relationship between growth and inequality. Ravallion (1997) suggests that higher growth with high level of inequality may not reduce poverty level of a country.

\section{References}

Ali, S S and S Tahir (1999). Dynamics of Growth, Poverty, and Inequality in Pakistan. Pakistan Development Review, 38: 837-58.

Araar, A (2006). On the Decomposition of the Gini Coefficient: An Exact Approach, with an Illustration Using Cameroonian Data. Working Paper 06-02. CIRPÉE.

Araar, A and A T Timothy (2006). Poverty and Inequality Nexus: Illustration with Nigerian Data Working Paper 06-38. CIRPEE, Cahier de recherché.

Bils, M and P J Klenow (2000). Does Schooling Cause Growth?. American Economic Review, 90: 116083.

Datt, G and M Ravallion (1992). Growth and Redistribution Components of Changes in Poverty Measures: a Decomposition with Applications to Brazil and India in the 1980's Journal of Development Economics, 38: 275-95.

Deaton, A and V Kozel (2005). Data and Dogma: The Great Indian Poverty Debate World Bank Research Observer, 20: 177-99.

Deaton, A and J Dreze (2002). Poverty and Inequality in India: A Re-Examination. Economic and Political Weekly, 37: 3729-48.

Foster, J, J Greer and T Thorbecke (1984). A Class of Decomposable Poverty Measures Econometrica, 52: 761-65.

Gangopadhyay, S, P Lanjouw, T Vishwanath, and N Yoshida (2010). Identifying Pockets of Poverty: Insights from Poverty Mapping Experiments in Andhra Pradesh, Orissa and West Bengal Indian J ournal of Human Development, 4: 5-28.

Glaeser, E L, M Resseger and K Tobio (2009), Inequality in Cities. Journal of Regional Science, 49: 61746.

Government of India (2009). India: Urban Poverty Report 2009. Ministry of Housing and Urban Poverty Alleviation (ed). New Delhi: Oxford University Press.

Haughton, J and S R Khandker (2009). Hand Book on Poverty and Inequality. Washington DC.: The World Bank.

J ha, R (2002). Reducing Poverty and Inequality in India: Has Liberalization Helped?. Working Papers 2002-04. Australian National University, Arndt-Corden Department of Economics.

Krugman, P (1991). Increasing Returns and Economic Geography. Journal of Political Economy, 99: 483-99.

Kundu, A (2006) Trends and Patterns of Urbanization and their Economic Implications. India Infrastructure Report 2006. New Delhi: Oxford University Press, Chapter 2, Pp 27-41.

Kundu, A and N Sarangi (2005). Issue of Urban Exclusion. Economic and Political Weekly, 40: 3642-46.

Kuznets, S (1955). Economic Growth and Income Inequality. American Economic Review, 45: 1-28. 
Le, H Q (2010). The Linkages between Growth, Poverty and Inequality in Vietnam: An Empirical Analysis. Working Paper Series No. 2010/06. DEPOCEN.

Ravallion, M (1997). Can High-Inequality Developing Countries Escape Absolute Poverty? Economic Letters, 56: 51-57.

Sen, A and Himanshu (2004). Poverty and Inequality in India-I. Economic and Political Weekly, 39: 4247-63.

Sundaram, K and S D Tendulkar (2003). Poverty in India in the 1990s: An Analysis of Changes in 15 Major States. Economic and Political Weekly, 38: 1385-93.

Vaidyanathan, K E (2001). Measurement of Income Inequalities in Urban and Rural Areas in India. Paper presented in the $53^{\text {rd }}$ Session of the International Statistical Institute, Seoul.

World Bank (2004). India: Investment Climate and Manufacturing Industry. Washington, DC: The World Bank.

(2010). Perspectives on Poverty in India: Stylized Facts from Survey Data India Poverty Assessment, Poverty Reduction and Economic Management Network, The World Bank. 


\section{Recent Working Papers}

227 Environmental Efficiency of the Indian Cement I ndustry: An Interstate Analysis Sabuj Kumar Mandal andS Madheswaran

228 Determinants of Living Arrangements of Elderly in Orissa: An Analysis Akshaya Kumar Panigrahi

229 Fiscal Empowerment of Panchayats in India: Real or Rhetoric? M Devendra Babu

230 Energy Use Efficiency in Indian Cement Industry: Application of Data Envelopment Analysis and Directional Distance Function

Sabuj Kumar Mandal and S Madheswaran

231 Ethnicity, Caste and Community in a Disaster Prone Area of Orissa Priya Gupta

232 Koodankulam Anti-Nuclear Movement: A Struggle for Alternative Development? Patibandla Srikant

233 History Revisited: Narratives on Political and Constitutional Changes in Kashmir (1947-1990)

Khalid Wasim Hassan

234 Spatial Heterogeneity and Population Mobility in India Jajati Keshari Parida and S Madheswaran

235 Measuring Energy Use Efficiency in Presence of Undesirable Output: An Application of Data Envelopment Analysis (DEA) to I ndian Cement I ndustry Sabuj Kumar Mandal and S Madheswaran

236 Increasing trend in Caesarean Section Delivery in India: Role of Medicalisation of Maternal Health Sancheetha Ghosh

237 Migration of Kashmiri Pandits: Kashmiriyat Challenged? Khalid Wasim Hassan

238 Causality Between Energy Consumption and Output Growth in Indian Cement Industry: An Application of Panel Vector Error Correction Model

Sabuj Kumar Mandal and SMadheswaran

239 Conflict Over Worship:A Study of the Sri Guru Dattatreya Swami Bababudhan Dargah in South India Sudha Sitharaman

240 Living Arrangement Preferences of the Elderly in Orissa, I ndia Akshaya Kumar Panigrahi

241 Challenges and Pospects in the Measurement of Trade in Services Krushna Mohan Pattanaik

242 Dalit Movement and Emergence of the Bahujan Samaj Party in Uttar Pradesh: Politics and Priorities Shyam Singh

243 Globalisation, Democratic Decentralisation and Social Secutiry in India

S N Sangita and T K J yothi
244 Health, Labour Supply and Wages: A Critical Review of Literature Amrita Ghatak

245 Is Young Maternal Age A Risk Factor for Sexually Transmitted Diseases and Anemia in India? An Examination in Urban and Rural Areas Kavitha N

246 Patterns and Determinants of Female Migration in I ndia: I nsights from Census Sandhya Rani Mahapatro

247 Spillover Effects from Multinational Corporations: Evidence From West Bengal Engineering I ndustries Rajdeep Singha and K Gayithri

248 Effectiveness of SEZs Over EPZs Structure: The Performance at Aggregate Level Malini L Tantri

249 Income, Income Inequality and Mortality An empirical investigation of the relationship in India, 1971-2003 K S J ames and T S Syamala

250 Institutions and their Interactions: An Economic Analysis of Irrigation Institutions in the Malaprabha Dam Project Area, Karnataka, I ndia Durba Biswas and L Venkatachalam

251 Performance of I ndian SEZs: A Disaggregated Level Analysis Malini L Tantri

252 Banking Sector Reforms and NPA: A study of I ndian Commercial Banks Meenakshi Rajeev and H P Mahesh

253 Government Policy and Performance: A Study of Indian Engineering I ndustry Rajdeep Singha and K Gayithri

254 Reproduction of Institutions through People's Practices: Evidences from a Gram Panchayat in Kerala Rajesh K

255 Survival and Resilience of Two Village Communities in Coastal Orissa: A Comparative Study of Coping with Disasters Priya Gupta

256 Engineering Industry, Corporate Ownership and Development: Are Indian Firms Catching up with the Global Standard? Rajdeep Singha and K Gayithri

257 Scheduled Castes, Legitimacy and Local Governance: Continuing Social Exclusion in Panchayats Anand Inbanathan and N Sivanna

258 Plant-Biodiversity Conservation in Academic Institutions: An Efficient Approach for Conserving Biodiversity Across Ecological Regions in India Sunil Nautiyal

259 WTO and Agricultural Policy in Karnataka Malini L Tantri and R S Deshpande 
260 Tibetans in Bylakuppe: Political and Legal Status and Settlement Experiences TungaTarodi

261 Trajectories of China's I ntegration with the World Economy through SEZs: A Study on Shenzhen SEZ Malnil L Tantri

262 Governance Reforms in Power Sector: I nitiatives and Outcomes in Orissa Bikash Chandra Dash and S N Sangita

263 Conflicting Truths and Contrasting Realities: Are Official Statistics on Agrarian Change Reliable? VAnil Kumar

264 Food Security in Maharashtra: Regional Dimensions Nitin Tagade

265 Total Factor Productivity Growth and Its Determinants in Karnataka Agriculture Elumalai Kannan

266 Revisiting Home: Tibetan Refugees, Perceptions of Home (Land) and Politics of Return

267 Nature and Dimension of Farmers' Indebtedness in I ndia and Karnataka Meenakshi Rajeev and B P Vani

268 Civil Society Organisations and Elementary Education Delivery in Madhya Pradesh Reetika Sya

269 Burden of I ncome Loss due to Ailment in India: Evidence from NSS Data Amrita Ghatak and S Madheswaran

270 Progressive Lending as a Dynamic Incentive Mechanism in Microfinance Group Lending Programmes: Empirical Evidence from I ndia

Naveen Kumar K and Veerashekharappa

271 Decentralisation and I nterventions in Health Sector: A Critical I nquiry into the Experience of Local Self Governments in Keral

M Benson Thomas and K Rajesh

272 Determinants of Migration and Remittance in India: Empirical Evidence J ajati Keshari Parida and S Madheswaran

273 Repayment of Short Term Loans in the Formal Credit Market: The Role of Accessibility to Credit from Informa Sources Manojit Bhattacharjee and Meenkashi Rajeev Tarodi Tunga

274 Special Economic Zones in I ndia: Are these Enclaves Efficient? Malini L Tantri

275 An Investigation into the Pattern of Delayed Marriage in I ndia Baishali Goswami

276 Analysis of Trends in I ndia's Agricultural Growth Elumalai Kannan and Sujata Sundaram

277 Climate Change, Agriculture, Poverty and Livelihoods: A Status Report K N Ninan and Satyasiba Bedamatta

278 District Level NRHM Funds Flow and Expenditure: Sub National Evidence from the State of Karnataka K Gayithri

279 I n-stream Water Flows: A Perspective from Downstream Environmental Requirements in Tungabhadra River Basin

K Lenin Babu and B K Harish Kumara

280 Food I nsecurity in Tribal Regions of Maharashtra: Explaining Differentials between the Tribal and Non-Tribal Communities Nitin Tagade

281 Higher Wages, Cost of Separation and Seasonal Migration in India J ajati Keshari Parida and S Madheswaran

282 Pattern of Mortality Changes in Kerala: Are they Moving to the Advanced Stage? M Benson Thomas and K S J ames

283 Civil Society and Policy Advocacy in India V Anil Kumar

284 I nfertility in I ndia: Levels, Trends, Determinants and Consequences T S Syamala

285 Double Burden of Malnutrition in I ndia: An I nvestigation Angan Sengupta and T S Syamala

286 Vocational Education and Child Labour in Bidar, Karnataka, I ndia V Anil Kumar

287 Politics and Public Policies: Politics of Human Development in Uttar Pradesh, India

Shyam Singh and V Anil Kumar

288 Understanding the Fiscal Implications of SEZs in I ndia: An Exploration in Resource Cost Approach Malini L Tantri

Price: Rs. 30.00

ISBN 978-81-7791-145-9

\section{InSTITUTE For SOCIAL AND ECONOMIC CHANGE}

Dr V K R V Rao Road, Nagarabhavi P.O., Bangalore - 560 072, India

Phone: 0091-80-23215468, 23215519, 23215592; Fax: 0091-80-23217008

E-mail: lekha@isec.ac.in; Web: www.isec.ac.in 